\title{
Article \\ Nudge the Lunch: A Field Experiment Testing Menu-Primacy Effects on Lunch Choices
}

\author{
Ola Andersson 1,2,* and Lif Nelander 1,3 \\ 1 Department of Econonomics and UCFS, Uppsala University, SE-751 21 Uppsala, Sweden; \\ lif.nelander@wsp.com \\ 2 Research Institute of Industrial Economics, SE-751 21 Uppsala, Sweden \\ 3 WSP, SE-121 88 Stockholm, Sweden \\ * Correspondence: ola.andersson@nek.uu.se
}

check for updates

Citation: Andersson, O.; Nelander, L.

Nudge the Lunch: A Field

Experiment Testing Menu-Primacy

Effects on Lunch Choices. Games 2021,

12, 2. https://doi.org/10.3390/

g12010002

Received: 27 November 2020

Accepted: 30 December 2020

Published: 5 January 2021

Publisher's Note: MDPI stays neutral with regard to jurisdictional clai$\mathrm{ms}$ in published maps and institutional affiliations.

Copyright: $\odot 2021$ by the authors. Licensee MDPI, Basel, Switzerland. This article is an open access article distributed under the terms and conditions of the Creative Commons Attribution (CC BY) license (https:// creativecommons.org/licenses/by/ $4.0 /)$.

\begin{abstract}
By way of a field experiment conducted at a university cafeteria this paper finds that placing a vegetarian option instead of a meat option at the top of a menu decreases the share of meat dishes sold by $11 \%$. This translates to a $6 \%$ decrease of daily emissions due to food sales. Using data on payment method, we find that the result is most likely driven by non-students responding to the nudge.
\end{abstract}

Keywords: behavioral economics; limited attention; salience; nudging; sustainable food consumption; field experiment; menu intervention

\section{Introduction}

A nudge [1] is described as a small, non-intrusive push that promotes a more desirable outcome for the individual as well as for society. One setting where a nudge may have a big impact is the choice of what to have for lunch. Such decisions are often made swiftly without deliberation, simply picking the meal option that grabs attention on the menu. Compared to fish or vegetarian options, meat has a more profound impact on the amount of greenhouse gas (GHG) emissions [2-4], making it environmentally desirable to reduce such choices.

This study analyses if a small nudge that reduces the salience of ordering a meat dish can push individuals to make a more sustainable choice when choosing what to eat. We do this by conducting a field experiment [5] at a university restaurant where we randomly assign the menu order each day, with either a meat or a vegetarian option at the top of a uniformly priced, three-option menu. We find that replacing a meat option with a vegetarian option at the top of the menu significantly reduces the number of meat dishes ordered by $11 \%$. This reduction in meat dishes is in turn spread out over the vegetarian and fish options available, increasing each of these albeit not significantly so. Perhaps more importantly, as the GHG emissions from a fish or a vegetarian option is lower than the GHG emissions from a meat option, the goal of reducing such emissions may be successful with this type of nudge. Using data on different loyalty cards we also find that the effect of the nudge is heterogeneous. Students using a student loyalty card are not significantly affected by the nudge to eat less meat. In contrast, regulars using a customer card and occasional customers not using a loyalty card are significantly affected by the nudge, reducing their consumption of meat.

It is well anchored in society that we are facing a global climate crisis. To reach the goal of keeping the global surface temperature below a $2{ }^{\circ} \mathrm{C}$ increase [6], action must be taken and the amount of GHG emissions has to drastically be reduced. Public policy has potential to play a major role in the collective step towards a more sustainable lifestyle. Looking at the patterns of an individual's total emissions per year, food consumption accounts for one fifth [7]. Hedenus et al. [8] conclude that dietary changes are essential to reach the $2{ }^{\circ} \mathrm{C}$ goal. 
Using nudges is a relatively cheap and easy intervention since they are defined to be small and not cause major changes to the choice architecture ([1], p. 6). Research on nudging in food related contexts has shown effective results as food decisions are often considered to be taken without using a large amount of cognitive thinking [9-12]. It is reported that in 2018, meat accounted for one third of the average household emissions due to food consumption (and as mentioned, food consumption in general accounts for one fifth of the total average household emissions) [7]. The GHG emissions vary depending on the type of meat, but in general a completely plant-based meal does cause lower levels of GHG emissions. Taking a collective step towards more plant-based and vegetarian food options is therefore argued to be of importance in the process of reducing the GHG emissions and reaching goals set $[8,13]$. Emission reductions are well anchored goals on all levels of the society; at organizations such as the UN and OECD, at all political levels as well as within business sectors. In this vein, the Paris Agreement, signed by 195 countries, aims to strengthen the response to the increasing threats of climate change and keep the global temperature rise below $2{ }^{\circ} \mathrm{C}[6]$ and is used as guidelines in many contexts. The demand for policy interventions aimed towards a more sustainable food consumption is widespread but how it should be formulated to be effective is yet to be established. A recent meta-study of different interventions shows that nudges has the potential to be effective but calls for more research on this topic [14].

Deciding what to eat is not a protracted process, it is something we do multiple times every day, it usually goes fast, works effectively without major effort invested and is a relatively mindless action of ours. ${ }^{1}$ Hence environmental cues in the food decision environment can play an important role on the choice. Changes in the menu design thus has the potential to make the recommended behavior the more salient choice.

Primacy effects, a concept that has been developed over a long period of time and is well established in the literature, describe how options presented first causes a bias to prefer that option when presented in a list [16-18]. Evidence for this has been found when looking at the order of names on voting slips, increased demand for firms positioned at the top in search engines, prices on identical items auctioned off and which research papers are downloaded and cited when presented on a list [19-24]. Thus, a nudge that places the desired meal choice at the top of the menu may be effective in achieving a healthier and more sustainable choice. This is the main hypothesis we set out to test in this paper.

A menu's design has various different features that can be altered and affect the final outcome of what option the customer at the restaurant chooses. The design can nudge people towards a certain choice by shifting attention, enhancing taste expectations and increasing perception of value [25]. Using descriptive names and recommendation labels are cues aimed towards the customer's expectations. This can bias the perception and lead to a different choice. Drawing the attention to certain items with visual cues such as different fonts, colors and illustrations have also been explored [26-28].

There exists a relatively large body of research regarding environmental cues in food related situations, most of it focusing on health aspect of our food consumption. On average we make 200 food related decisions a day [29] many without any, or limited, cognitive evaluation involved. In many countries today, the largest economies US and China being prime examples [30], obesity is a major public health issue and nudging has been implemented with the purpose of having consumers choose the healthier option, as well as to reduce the amount of food consumed. The way the food is presented, the convenience to order the healthier options, size of portions and increased nutritional labeling have been tested and the results show a large potential for small interventions, nudges, to be efficient [9-12,31].

Promoting more sustainable food choices by using nudges has been less explored, although a small body of research can be found. Experiments where a small inconvenience

1 In line with this argument Garnett et al. [15] shows that simply increasing the share of vegetarian options on the menu significantly increases the share of these dishes purchased. 
to order meat is introduced, using carbon emission labeling in grocery stores, changing menu design at restaurants and displaying nutrition and carbon labels next to the meals [27,32-34] have been done and in general positive effects on choosing the more sustainable option are seen.

Evidence on the pure effect of menu order is still scarce but starting to accumulate. In a recent study Kurz [35] investigates how altering the menu order at a university restaurant to display the vegetarian option first affect meal orders. She finds a 6-percentage-point reduction of meat-dish orders, an estimate close to ours. However, in the study both the order of the menu and the visual display is changed simultaneously, thus a causal impact of the menu order in isolation is still needed. An indication that the menu order alternation was a driving factor was found as the change of menu order was implemented at the control restaurant for a selected time, without any visual stimuli accompanying the change [35]. In addition, Kurz uses a pre-treatment control period followed by an intervention period to identify a potential effect of the nudge. Our study complements the study by Kurz and further investigates the menu order effect by isolating this effect within a purely randomized design.

In a study close to ours, Gravert and Kurz [32] look at the effect of excluding either the meat option or the vegetarian option from the main menu, only having a note attached to the menu noting that an unspecified corresponding dish could be ordered by request. The different menus were handed out in two different parts of the restaurant (front and back), thus randomization to treatment relied on random assignment of customers to seats. Using this more intrusive nudge they find that excluding the meat dish reduces orders of this dish by $25 \%$, a substantially larger effect than the one found in our and the Kurz [35] study. So, like us they have a randomized design (given that there was randomization of customers to seats) but compared to our nudge, theirs is rather intrusive as it requires customers inquiring about the details of the excluded dish. We think that we complement Gravert and Kurz [32] by showing that significant effects, albeit smaller in size, can be obtained by way of a less intrusive nudge.

The paper is outlined as follows: Section 2 outlines the experimental design of the nudge. Section 3 describes the data used for the analysis while Section 4 presents the descriptive statistics and the regression results. The results are then discussed in Section 5 and Section 6 concludes.

\section{Experimental Design}

In the following subsections the design and context of the field experiment are outlined.

\subsection{Cafeteria Setting}

The study took place at the university cafeteria Kaffebaren Ångströms located at Ångströmslaboratoriet in Uppsala, Sweden. Ångströmslaboratoriet is the campus for the departments of Mathematics, Physics and Astronomy, Technology, Chemistry and the Institute of Space Physics at Uppsala University. The cafeteria is a part of Högskolerestauranger $\mathrm{AB}$, a company which operates university cafeterias in nine university cities in Sweden and is one of four cafeterias run by Högskolerestauranger AB in Uppsala. Three warm dishes were served for lunch at the cafeteria every day, always at least one meat and one vegetarian option. The third dish varied somewhat, the majority of the time it was a fish option, sometimes a second vegetarian and occasionally a second meat option. The warm lunch was available for purchase between 11.00 and 14.00 each weekday. The same price applied to all options but vary between customers depending on if they were holding a loyalty card or not. There were two types of pre-paid loyalty cards, one student card and one customer card. ${ }^{2}$

Having uniform prices for all the options is good for the experimental set up as it isolates any price effect from the results. The outline of the cafeteria can be seen in

2 We perform a subsample analysis for different types of cards in Section 4.3. 
Figure A1 in the Appendix A. There was one line for the customers to reach the counter and depending on from where they arrived at the cafeteria they faced either one or two menu boards where the different lunch options were presented. Examples of the menu boards are shown in Figures A2 and A3 in the Appendix A. On the right-hand side of the options on the first menu board information regarding opening hours and prices along with two still life photos were displayed, all of which were constant throughout the study period. The customers ordered at the counter, received the food right away and then paid. Hence there were no serving at the table and the customers did not receive an individual menu from a waiter.

Accompanied with the name and description of each option on the menu, the amount of carbon dioxide equivalents $\left(\mathrm{CO}_{2} \mathrm{e}\right)$ emissions for each option were displayed. The number of kilograms $\mathrm{CO}_{2}$ e per each standard portion was shown along with a colored bar of different length and color depending on how large the emission was. In addition, icons indicating the allergens present in each option were displayed, e.g., gluten, soy or milk protein.

\subsection{Randomization}

The assignment of the top item was determined by a random draw before the study took place. The days were sorted according to a random number generated and the top half was assigned to the treatment group while the bottom half was assigned to the control group, thus a randomization ratio of 1:1 was assigned yielding balanced groups. Placing the vegetarian option at the top of the menu will be considered treatment and having the meat option at the top will be the control. For the days when a fish option was available it was placed in the middle and when so is not the case, the third option, either vegetarian or meat, was in the middle position. The order the options were the same on the two menu boards in the cafeteria.

\subsection{Customers}

The number of customers varied, but typically between 100 and 200 warm lunches were sold each day (see Table 1 for descriptive statistics). The cafeteria was open to everyone, but it was mainly the people who work and study at the departments housed at Angströmslaboratoriet that composed the daily customer group. Hence, there were many regulars buying warm lunch from the cafeteria several times a week. This is good for the identification strategy of the randomization since the chance that the one same person buys lunch both on a treated and a controlled day increases with many regulars. Unfortunately, the data does not allow us to track the purchases of one person across days.

\subsection{Design Issues}

There is one additional way in which the customer could obtain information about what different options are offered each day, the website. On the website, as opposed to the physical menus in the cafeteria, the customer could also view the weekly menu. The meat option was always displayed at the top of the menu on the website for the first part of the period, both for the daily and weekly menus. It was noted as the experiment went on that as from 1 April, six weeks into the schedule of randomization, the vegetarian option was placed at the top of the menu online. This might cause some noise to the results. However, since the customer was always exposed to the physical menu boards before the purchase, that should be the most recent information before the purchase was made. What might offset the effect is if the customer had decided on what option to choose in advance after having considered the website menu and sends someone else to buy it. Then the nudge will have no influence on those purchases which might reduce the effect of the treatment. The risk that this is commonly done is not considered to be large enough to affect the results, however.

A potential mechanism that may affect the regression results is if there are any carryover effects. Carryover effects exist if a person, who has been buying lunch during 
several treatment days, comes during a control day and is still affected by having seen the vegetarian option at the top in the previous days, i.e., the person gets nudged also when the physical nudge is not there. This might be present due to the usage of randomized treatment rather than having a control period prior to the treatment period. We control for this by adding a variable that keeps track of the menu order the day before and it does not affect our main conclusions.

Another feature of the experimental set up that might offset the effect of the altered menu order is the color labeling feature of the menu. It is a strong illustrative part of the menu display and catches the attention of the eye (see Figures A2 and A3). If the effect of the color labeling is stronger, and customers look more on that feature of the menu rather than just sequentially reading what the different options are, the treatment effect will be reduced as it will not matter as much where on the menu it is placed.

Lastly, an additional mechanism that may affect the results is if one of the daily options offered ran out and customers who might have wanted that option were forced to choose something else. If this happened to the meat option offered during a treatment day for example (which was the most popular option throughout the intervention period, see Table 1), it would be as if there were a treatment effect but really the vegetarian option was chosen because there were no more of the meat option available. The restaurant did not record which days or for what option this happened, but stated in personal communication that it does not happen very often.

The offsetting mechanisms outlined above will introduce noise and potentially put a downward bias to the estimates.

Prior to getting access to any data the study was pre-registered on Open Science Framework [36]. This was done to ensure transparency of both the design and the method of analysis. However, since we did not have access to the data at the time of the registration (which is consensus), some additional tests will be run. The main specifications however remain the same as those reported in the pre-registration and when so is not the case it will be stated clearly.

\section{Data}

Data was gathered between 18 February to 30 April 2019, resulting in a sample of 50 days in total (Mondays-Fridays), 25 treatment days and 25 control (as the randomization is made such that the treatment and control group balance). The number of sales per day varied between 100 and 200 generating a data set with a total of 7968 sales.

In addition to the data covering the daily sales, the daily menus were downloaded from the company's website to categorize each option based on its main component. Data for $\mathrm{CO}_{2} \mathrm{e}$ emissions for each meal is retrieved from the CarbonAte software (CarbonCloud, Gothenburg, Sweden). Data regarding what type of payment each purchase was made with was provided through the back-office program the company uses. Access to this data allows for a more refined analysis of the treatment effect within different customer segments.

The data was delivered as aggregated numbers from the daily cash registers. Due to misreported purchases some of the days when no fish option is on the menu, there were still some purchases done where fish is registered. The misreported values will be handled by dividing them randomly to the meat and vegetarian counts. As the restaurant could not say what options they misreported, it can be seen as random if it was a vegetarian or a meat purchase recorded as fish. As sensitivity analysis and robustness checks, other approaches are conducted in Appendix B.3 of the Appendix B.

\section{Results}

This section sets out by presenting the descriptive statistics and then goes on to perform statistical analyses. 


\subsection{Descriptive Statistics}

In Table 1, descriptive statistics of the collected data are shown. A difference between the number of vegetarian options sold during treatment and control days is not obvious. For meat, the difference is larger and in the opposite direction, on average 7.78 less meat options were sold during treatment days compared to control days.

Considering the shares of the different options sold, for the vegetarian option the total share is almost the same for both groups. For the fish option the average share is lower during control days and for meat the average share sold is higher during control days than during treatment days. When remembering that during some days two vegetarian or two meat options were offered and accounting for that, the average shares are more reasonable, and a smaller share of vegetarian options sold during controls days is seen, 0.23 compared to 0.24 during treatment days, on average. It is clear that meat is the most popular option overall, followed by fish during those days when fish is served (see lower panel in Table 1) and lastly the vegetarian option. The shares for vegetarian and fish options sold are overall closer to each other $(0.24$ respectively 0.27$)$ than what the share of meat is $(0.50)$.

Table 1. Descriptive statistics.

\begin{tabular}{lcccccc}
\hline Variables & $\begin{array}{c}\text { Control } \\
\text { Mean }\end{array}$ & SD & $\begin{array}{c}\text { Treatment } \\
\text { Mean }\end{array}$ & SD & $\begin{array}{c}\text { Total } \\
\text { Mean }\end{array}$ & SD \\
\hline No. veg sold/day & 49.84 & 22.50 & 47.40 & 23.33 & 48.62 & 22.72 \\
No. meat sold/day & 91.52 & 22.88 & 78.04 & 24.89 & 84.78 & 24.62 \\
Avg. no. veg sold/day & 36.14 & 10.54 & 37.48 & 13.70 & 36.81 & 12.12 \\
Avg. no. meat sold/day & 83.26 & 18.80 & 75.48 & 25.58 & 79.37 & 22.56 \\
Veg share & 0.31 & 0.12 & 0.30 & 0.15 & 0.31 & 0.14 \\
Meat share & 0.57 & 0.09 & 0.49 & 0.11 & 0.53 & 0.11 \\
Avg. veg share & 0.23 & 0.06 & 0.24 & 0.08 & 0.24 & 0.07 \\
Avg. meat share & 0.52 & 0.08 & 0.48 & 0.11 & 0.50 & 0.10 \\
Total & 162.44 & 31.93 & 156.28 & 24.08 & 159.36 & 28.17 \\
\hline Observations (days) & 25 & & 25 & & 50 & \\
\hline No. fish & 43.92 & 11.24 & 42.83 & 13.70 & 43.27 & 12.58 \\
Fish share & 0.26 & 0.05 & 0.28 & 0.11 & 0.27 & 0.09 \\
\hline Observations (days) & 12 & & 18 & & 30 & \\
\hline
\end{tabular}

\subsection{Regression Analysis}

We use an ordinary least square (OLS) regression to test our main hypotheses. ${ }^{3}$ The dependent variables are the shares of meat, vegetarian or fish dishes ordered at each date $t$, depvar $_{t}=\left\{\right.$ meatshare $_{t}$, vegshare $_{t}$, fishshare $\left._{t}\right\}$. The model is specified as in Equation (1).

$$
\text { depvar }_{t}=\alpha+\beta \times \text { treatment }_{t}+\mathbf{x}_{\mathbf{t}}+\gamma_{t}+u_{t},
$$

where treatment $t$ is a binary variable taking the value 1 during treatment days, when the vegetarian option is placed at the top of the menu board and 0 during control days, when the meat option is placed at the top of the menu board. $\beta$ captures the estimated effect of placing the vegetarian option at the top of the menu on the share of vegetarian options sold. $\mathbf{x}_{\mathbf{t}}$ is a vector of factor variables of which the estimates will be conditioned on, as defined in Table 2. $\gamma_{t}$ is weekday fixed effects, outlined as a set of binary variables for each weekday. $\alpha$ is the constant.

The days when no fish was served and either two vegetarian or two meat options were on the menu occurs at least once a week throughout the whole intervention period. As this was not known prior to the pre-registration of the study, these variables are not mentioned to be included in the vector of factor variables in the pre-registration. So is the

3 As suggested by a referee an alternative approach would have been to jointly estimate all decisions using a multinomial logit model. An upside with this approach is that the choice of dishes is estimated jointly. However, the pre-registration dictates the chosen route here. 
case for the $\mathrm{CO}_{2} \mathrm{e}$ variables and the day after treatment variable. Weekday fixed effects will also be controlled for. The variables in Table 2 will be sequentially added to the different specifications.

Table 2. Factor variables to condition the estimates on.

\begin{tabular}{ll}
\hline Treatment & Binary variable, 1 if treatment day, 0 if control day \\
\hline Dummy for 2 meat & Binary variable, 1 if two meat options were offered, 0 otherwise \\
\hline Dummy for 2 veg & Binary variable, 1 if two vegetarian options were offered, 0 otherwise \\
\hline Day after treatment & $\begin{array}{l}\text { Binary variable, } 1 \text { if the day before was a treatment day, } \\
\text { 0 if was a control day }\end{array}$ \\
\hline Avg. $\mathrm{CO}_{2}$ e meat option & $\begin{array}{l}\text { Average } \mathrm{CO}_{2} \mathrm{e} \text { emissions for the meat dish of the day } \\
\text { (if two meat options were served, the average } \mathrm{CO}_{2} \mathrm{e} \text { emissions of those } \\
\text { is used) }\end{array}$ \\
\hline Avg. $\mathrm{CO}_{2}$ e vegetarian option & $\begin{array}{l}\text { Average } \mathrm{CO}_{2} \text { e emissions for the vegetarian dish of the day } \\
\text { (if two vegetarian options were served, the average } \mathrm{CO}_{2} \mathrm{e} \text { emissions of } \\
\text { those is used) }\end{array}$ \\
\hline $\mathrm{CO}_{2} \mathrm{e}$ fish option & $\mathrm{CO}_{2} \mathrm{e}$ emissions for the fish option of the day \\
\hline
\end{tabular}

The estimated effects of the treatment, placing the vegetarian option at the top of the menu, on the share of meat options sold are presented in Table 3. The results show a strong treatment effect, and the estimates are significantly negative for all specifications. On average, the estimated effect ranges between -5.30 and -7.19 percentage points, with most of the specifications reporting an average estimated effect of around -5.5 percentage points. This implies that placing the vegetarian option at the top of the menu on average decreases the share of meat option sold that day by 5.5 percentage points, compared to when the vegetarian option is placed at the bottom of the menu and the meat option is placed at the top. Conditioning the estimates on that the day before was a treatment day marginally changes the estimated treatment effect compared to the preferred specification in column (2), increasing it from -0.0560 to -0.0530 . The effect of also controlling for what the menu order was the day before is not statistically significant. Controlling for the average $\mathrm{CO}_{2} \mathrm{e}$ emissions options available that day does not affect the general treatment effect (column (5)).

Specifically, considering the estimated effect from column (2) in Table 3, which is the preferred specification, the share of meat options purchased will on average decrease by 5.60 percentage points when the vegetarian option is placed at the top of the menu compared to when the meat option is placed at the top. ${ }^{4}$

The estimated effects of the treatment, placing the vegetarian option at the top of the menu, on the share of vegetarian dishes sold are presented in Table 4. In sum, placing the vegetarian option at the top of the menu does not significantly increase the share of vegetarian options sold. Only the specification in column (4) and (6) give statistically significant estimates $(p$-value $<0.1$ ) and disclose a small positive effect of 3.86 and 4.27 percentage points on average on the share of vegetarian option sold during treatment days. Controlling for if yesterday was treatment day only marginally affects the estimates for the treatment effect. Specifications conditioning the estimated effect on if two vegetarian options were served report positive, yet statistically insignificant, treatment effects. Con-

4 Considering the average share of meat option sold for the whole sample, 0.50 , a negative effect of 5.60 percentage points on average would imply that the average share of meat option sold decreases to $0.50-0.0560=0.444$. 
trolling for the average $\mathrm{CO}_{2}$ e emissions of the options available that day does not affect the overall treatment effect. ${ }^{5}$

Table 3. Share of meat option sold.

\begin{tabular}{lcccccc}
\hline & $\mathbf{( 1 )}$ & $\mathbf{( 2 )}$ & $\mathbf{( 3 )}$ & $\mathbf{( 4 )}$ & $\mathbf{( 5 )}$ & $\mathbf{( 6 )}$ \\
\hline Variables & \multicolumn{7}{c}{} & & & & \\
\hline Treatment & $-0.0719^{* * *}$ & $-0.0560^{* * *}$ & $-0.0547^{* *}$ & $-0.0605^{* *}$ & $-0.0570^{* *}$ & $-0.0530^{*}$ \\
& {$[0.0282]$} & {$[0.0249]$} & {$[0.0264]$} & {$[0.0259]$} & {$[0.0269]$} & {$[0.0267]$} \\
\hline Dummy for 2 meat & & $0.181^{* * *}$ & $0.179^{* * *}$ & 0.134 & 0.0963 & 0.137 \\
& & {$[0.0243]$} & {$[0.0239]$} & {$[0.0973]$} & {$[0.103]$} & {$[0.0937]$} \\
\hline Dummy for 2 veg & & 0.0113 & 0.0108 & -0.0328 & -0.0588 & -0.0299 \\
& & {$[0.0259]$} & {$[0.0263]$} & {$[0.0942]$} & {$[0.0965]$} & {$[0.0897]$} \\
\hline Total & & 0.000241 & 0.000321 & 0.000505 & 0.000277 \\
& & & {$[0.000616]$} & {$[0.000597]$} & {$[0.000631]$} & {$[0.000588]$} \\
\hline Day after treatment & & & & & -0.0185 \\
& & & & & {$[0.0258]$} \\
\hline Constant & $0.565^{* * *}$ & $0.540^{* * *}$ & $0.501 * * *$ & $0.510 * * *$ & $0.515 * * *$ & $0.518^{* * *}$ \\
& {$[0.0174]$} & {$[0.0170]$} & {$[0.105]$} & {$[0.103]$} & {$[0.105]$} & {$[0.102]$} \\
\hline Observations & 50 & 50 & 50 & 50 & 50 & 49 \\
Adjusted R-squared & 0.101 & 0.286 & 0.275 & 0.232 & 0.191 & 0.198 \\
Weekday fixed effects & $\mathrm{NO}$ & $\mathrm{NO}$ & $\mathrm{NO}$ & YES & YES & YES \\
Avg. CO ${ }_{2} \mathrm{e}$ & $\mathrm{NO}$ & $\mathrm{NO}$ & $\mathrm{NO}$ & $\mathrm{NO}$ & YES & NO \\
\hline
\end{tabular}

Robust standard errors in brackets, ${ }^{* * *} p<0.01,{ }^{* *} p<0.05,{ }^{*} p<0.1$.

Table 4. Share of vegetarian option sold.

\begin{tabular}{|c|c|c|c|c|c|c|}
\hline & (1) & (2) & (3) & (4) & (5) & (6) \\
\hline \multicolumn{7}{|l|}{ Variables } \\
\hline \multirow[t]{2}{*}{ Treatment } & -0.00338 & 0.0325 & 0.0304 & 0.0386 * & 0.0375 & $0.0427 *$ \\
\hline & {$[0.0387]$} & {$[0.0236]$} & {$[0.0233]$} & {$[0.0223]$} & {$[0.0233]$} & {$[0.0228]$} \\
\hline \multirow[t]{2}{*}{ Dummy for $2 \mathrm{veg}$} & & $0.249^{* * *}$ & $0.250 * * *$ & $0.128^{* * *}$ & $0.112^{* *}$ & $0.129 * * *$ \\
\hline & & {$[0.0256]$} & {$[0.0254]$} & {$[0.0315]$} & {$[0.0479]$} & {$[0.0313]$} \\
\hline \multirow[t]{2}{*}{ Dummy for 2 meat } & & $0.0754^{* *}$ & $0.0786^{* * *}$ & -0.0451 & -0.0547 & -0.0437 \\
\hline & & [0.0287] & {$[0.0269]$} & {$[0.0413]$} & {$[0.0605]$} & {$[0.0412]$} \\
\hline \multirow[t]{2}{*}{ Total } & & & -0.000408 & $1.44 \times 10^{-5}$ & $2.49 \times 10^{-6}$ & $4.99 \times 10^{-6}$ \\
\hline & & & {$[0.000420]$} & [0.000405] & [0.000471] & [0.000402] \\
\hline \multirow[t]{2}{*}{ Day after treatment } & & & & & & -0.00449 \\
\hline & & & & & & {$[0.0219]$} \\
\hline \multirow[t]{2}{*}{ Constant } & $0.308^{* * *}$ & $0.209^{* * *}$ & $0.275^{* * *}$ & $0.183^{* * *}$ & $0.185^{* * *}$ & $0.183^{* * *}$ \\
\hline & {$[0.0248]$} & {$[0.0190]$} & {$[0.0722]$} & {$[0.0620]$} & {$[0.0636]$} & {$[0.0623]$} \\
\hline Observations & 50 & 50 & 50 & 50 & 50 & 49 \\
\hline Adjusted R-squared & -0.021 & 0.658 & 0.658 & 0.662 & 0.641 & 0.653 \\
\hline Weekday fixed effects & $\mathrm{NO}$ & $\mathrm{NO}$ & $\mathrm{NO}$ & YES & YES & YES \\
\hline Avg. $\mathrm{CO}_{2} \mathrm{e}$ & $\mathrm{NO}$ & $\mathrm{NO}$ & $\mathrm{NO}$ & $\mathrm{NO}$ & YES & $\mathrm{NO}$ \\
\hline
\end{tabular}

Robust standard errors in brackets, ${ }^{* * *} p<0.01,{ }^{* *} p<0.05,{ }^{*} p<0.1$.

Extending the analysis and estimating the effect of the nudge on the daily shares of fish options sold, the same regression specifications are run. The results for the share of fish option sold as the outcome variable are presented in Table 5.

Table 5 presents the estimated effects of the regression specifications when the share of fish option sold is used as the outcome variable. The majority of the estimates are positive,

5 In Table A1 in the Appendix B, the estimated effects on the share of meat and vegetarian options sold when also conditioning on the type of dish are shown. Conclusions for those specifications need to be interpreted with caution due to the large number of conditional variables in relation to the sample size. 
but they vary in magnitude between the different specifications. The estimate reported in column (1) shows an average positive treatment effect of 1.68 percentage points on the share of fish option sold when the vegetarian option is placed at the top of the menu. However, none of the estimates reported in Table 5 are statistically significant, thus no clear trend in the effect of the nudge on the share of fish can be established. The number of observations when using the share of fish option sold is lower than for the regression specifications with other outcome variables (Tables 3 and 4). This is because the cafeteria during some days serve no fish and replace that option with either an additional vegetarian or meat option. Those days are excluded in the regression specifications in Table 5.

Table 5. Share of fish option sold.

\begin{tabular}{|c|c|c|c|c|c|}
\hline & (1) & (2) & (3) & (4) & (5) \\
\hline \multicolumn{6}{|l|}{ Variables } \\
\hline Treatment & $\begin{array}{c}0.0168 \\
{[0.0297]}\end{array}$ & $\begin{array}{l}0.00424 \\
{[0.0275]}\end{array}$ & $\begin{array}{l}0.00828 \\
{[0.0299]}\end{array}$ & $\begin{array}{c}0.0173 \\
{[0.0337]}\end{array}$ & $\begin{array}{c}-0.00842 \\
{[0.0281]}\end{array}$ \\
\hline Total & & $\begin{array}{c}-0.00138^{* *} \\
{[0.000628]}\end{array}$ & $\begin{array}{l}-0.00139 * \\
{[0.000714]}\end{array}$ & $\begin{array}{l}-0.00145^{*} \\
{[0.000796]}\end{array}$ & $\begin{array}{l}-0.00146^{*} \\
{[0.000730]}\end{array}$ \\
\hline Day after treatment & & & & & $\begin{array}{c}-0.00424 \\
{[0.0418]}\end{array}$ \\
\hline Constant & $\begin{array}{l}0.263^{* * *} \\
{[0.0154]}\end{array}$ & $\begin{array}{c}0.493^{* * *} \\
{[0.104]}\end{array}$ & $\begin{array}{c}0.490 * * * \\
{[0.119]}\end{array}$ & $\begin{array}{c}0.498^{* * *} \\
{[0.145]}\end{array}$ & $\begin{array}{c}0.516^{* * *} \\
{[0.132]}\end{array}$ \\
\hline Observations & 30 & 30 & 30 & 30 & 29 \\
\hline Adjusted R-squared & -0.027 & 0.087 & -0.011 & -0.085 & -0.007 \\
\hline Weekday fixed effects & $\mathrm{NO}$ & $\mathrm{NO}$ & YES & YES & YES \\
\hline Avg. $\mathrm{CO}_{2} \mathrm{e}$ & $\mathrm{NO}$ & $\mathrm{NO}$ & $\mathrm{NO}$ & YES & $\mathrm{NO}$ \\
\hline
\end{tabular}

Robust standard errors in brackets, ${ }^{* * *} p<0.01,{ }^{* *} p<0.05,{ }^{*} p<0.1$.

\subsection{Heterogeneous Effect of Nudge}

In what follows we perform a subsample analysis on different customer groups using the fact that students and regular customers (mostly faculty) has the option to pay using a loyalty card. This enables us to tie some of the effects to different groups although all customers have the option to buy at the regular price. To incentivize using a loyalty card the prices to students and regulars are 18 SEK and 10 SEK lower respectively than the regular price of 93 SEK. ${ }^{6}$ However, more importantly they are constant across the options offered.

Information on the type of payment method used enables us to make a subsample analysis of the effect of the nudge. The majority of the customers pay the full price of 93 SEK for a lunch, with an average of $42.2 \%$ for the whole intervention period. Student card payments account for $32.4 \%$ and customer card payments for $25.4 \%$, on average. Table 6 presents the regressions results by customer group for the share of meat-dish purchases, only including controls for whether two meat or two vegetarian options were offered and weekday fixed effects.

In general, the regression analysis shows similar trends as those obtained for the whole sample together, i.e., negative effect of the nudge on the share of meat option sold. However, the student card holders (column (2)) differ from the other two groups. First of all, the estimate for the treatment effect on the share of meat option sold is not statistically significant. ${ }^{7}$ The largest treatment effect found is on the share of meat option sold for the customer card holders, with a negative average effect of over 8 percentage points when the meat option is placed at the bottom of the menu board. For the largest group, the full price payers, the treatment effect is negative and statistically significant $(p<0.05)$.

610 SEK is approximately 0.8 USD at the time of the experiment. The student card is only available to students whereas the loyalty card is available to all.

7 Using a $t$-test on the treatment coefficients we find that the coefficient on the student card sample is significantly different from the other two groups. 
Table 6. Share of meat option sold per subsample.

\begin{tabular}{lccc}
\hline Variables & Customer Card & Student Card & Full Price \\
\hline Treatment & $-0.0872^{* *}$ & -0.0437 & $-0.0705^{* *}$ \\
& {$[0.0367]$} & {$[0.0286]$} & {$[0.0307]$} \\
\hline Dummy for 2 veg & 0.0439 & -0.0452 & -0.0466 \\
& {$[0.0446]$} & {$[0.0335]$} & {$[0.124]$} \\
\hline Dummy for 2 meat & $0.231^{* * *}$ & $0.109^{*}$ & 0.128 \\
& {$[0.0659]$} & {$[0.0558]$} & {$[0.132]$} \\
\hline Constant & $0.587^{* * *}$ & $0.526^{* * *}$ & $0.582^{* * *}$ \\
& {$[0.0556]$} & {$[0.0433]$} & {$[0.0576]$} \\
\hline Observations & 50 & 50 & 50 \\
Adjusted R-squared & 0.244 & 0.176 & 0.099 \\
Weekday fixed effects & YES & YES & YES \\
\hline Robust standard errors in brackets, ${ }^{* * *} p<0.01^{* *} p<0.05^{* *} p<0.1$. & &
\end{tabular}

\section{Discussion}

A possible explanation to why a clear treatment effect is found for the meat option but not the vegetarian and fish options might be that there is a larger level of substitution between the two latter. ${ }^{8}$ It might be even more so in the setting of this particular study as the fish and the vegetarian options are closer in terms of emissions per plate, which are visually expressed on the menu boards. The meat option is the option which is sold to the largest extent during both treatment and control days (see Table 1), i.e., the meat option is the most popular lunch among the customers at Kaffebaren Ångströms. The mechanism that would support the more prominent results when the share of meat sold is used as the outcome variable could be that when the vegetarian option is placed at the top of the menu, the customer considers what the option is but the probability that the next option is considered is higher. This due to the vegetarian option not being as popular as the meat option. During the control days, when the meat option is at the top of the menu board the probability that the customer considers the next option is lower. Due to the meat option being more popular it has a higher probability to be chosen straight away, without considering the next option.

The estimated effects across the different subgroups identified differ in some ways from those of the full sample. As seen in Table 6, the student card holders seem to be least affected by the nudge, while the estimates for the full price payers and the customer card holders are more similar to the estimates for the full sample. Since the price for all options are the same in each subsample, students in general have less money and meat is more expensive, one possible explanation can be that students who eat meat will choose that option independent of the menu order due to the unified price setting. However, another possible mechanism could be that more students in general are vegetarians and would therefore choose the vegetarian option no matter if it is a treatment and control day. This is seen in Table 6 where the constant for the student card holders is smaller than the constant for the customer card holders, although only marginally. The share of vegetarian option sold among student card holders is higher than the share of vegetarian option sold among customer card holders ( 0.129 for the customer card holders and 0.245 for the student card holders).

Behavioral spillovers can be both positive (adding to the effect) and negative (offsetting the effect). Thus, the claimed, although not perfectly evident, effect of the nudge, that individuals on average choose a more sustainable option for lunch and thereby reduce the effect on the climate, might be offset by behavioral spillover effects being present. Unfortunately, we cannot address these important questions with the data available in this study. This calls for further research. 
Another interesting venue for future research is to investigate how contrast of the attributes in choice set, such as the range of $\mathrm{CO}_{2} \mathrm{e}$, affect decisions. Such effects may be accounted for by salience theories (see e.g., Bordalo et al. [37]).

\section{Conclusions}

This study tests if it is possible to nudge customers to a more sustainable meal choice by altering the order of the menu. A field experiment is conducted at a university cafeteria in Uppsala, Sweden where the menu order is randomly assigned to be treatment (vegetarian option at the top) or control (meat option at the top). The results show a significant negative effect on the share of meat dishes sold when the vegetarian option is placed at the top of the menu board. It is, therefore, concluded that nudging people towards more sustainable choices is effective in food related environments. Since the total number of customers when the vegetarian option is placed at the top of the menu does not decrease, the significantly negative effect on the share of meat options sold causes positive effects on the shares of fish and vegetarian options sold. The effect is spread out and if more data were available, these positive effects may have been significant as well.

Although designed for the specific setting, the results from this study show that knowledge about human behavior can be used in policy making as an effective tool for reaching a more sustainable state of the world and thereby contribute to keeping the global temperature rise below $2{ }^{\circ} \mathrm{C}$, as is the generalized goal established by the UN. Indeed, our results corroborates those of Gravert and Kurz [32] and Kurz [35] and together we now provide quite solid evidence of the effectiveness of nudges in restaurant settings.

However, the design of nudges needs to be tailored to each specific situation. The external validity of this study needs to be carefully considered before the results can be generalized. The majority of the customers treated in this study are most likely highly educated. There is also a general trend in Sweden towards more climate-friendly food consumption. These are factors that might have led to that the nudge actually did affect the share of meat sold and it cannot be taken for granted that the same result would persist in a different environment. Further research is needed to close this knowledge gap.

Author Contributions: The authors have equally contributed to the writing of the paper. All authors have read and agreed to the published version of the manuscript.

Funding: We are thankful for financial support from Riksbankens Jubileumsfond and Handelsbankens forskningsstiftelse.

Acknowledgments: We want to thank Kaffebaren Ångström and Högskolerestauranger AB, especially Marlene Brolin and Linda Roslund, for making this study possible.

Conflicts of Interest: The authors declare no conflict of interest. 


\section{Appendix A}

\section{ÅNGSTRÖMS}
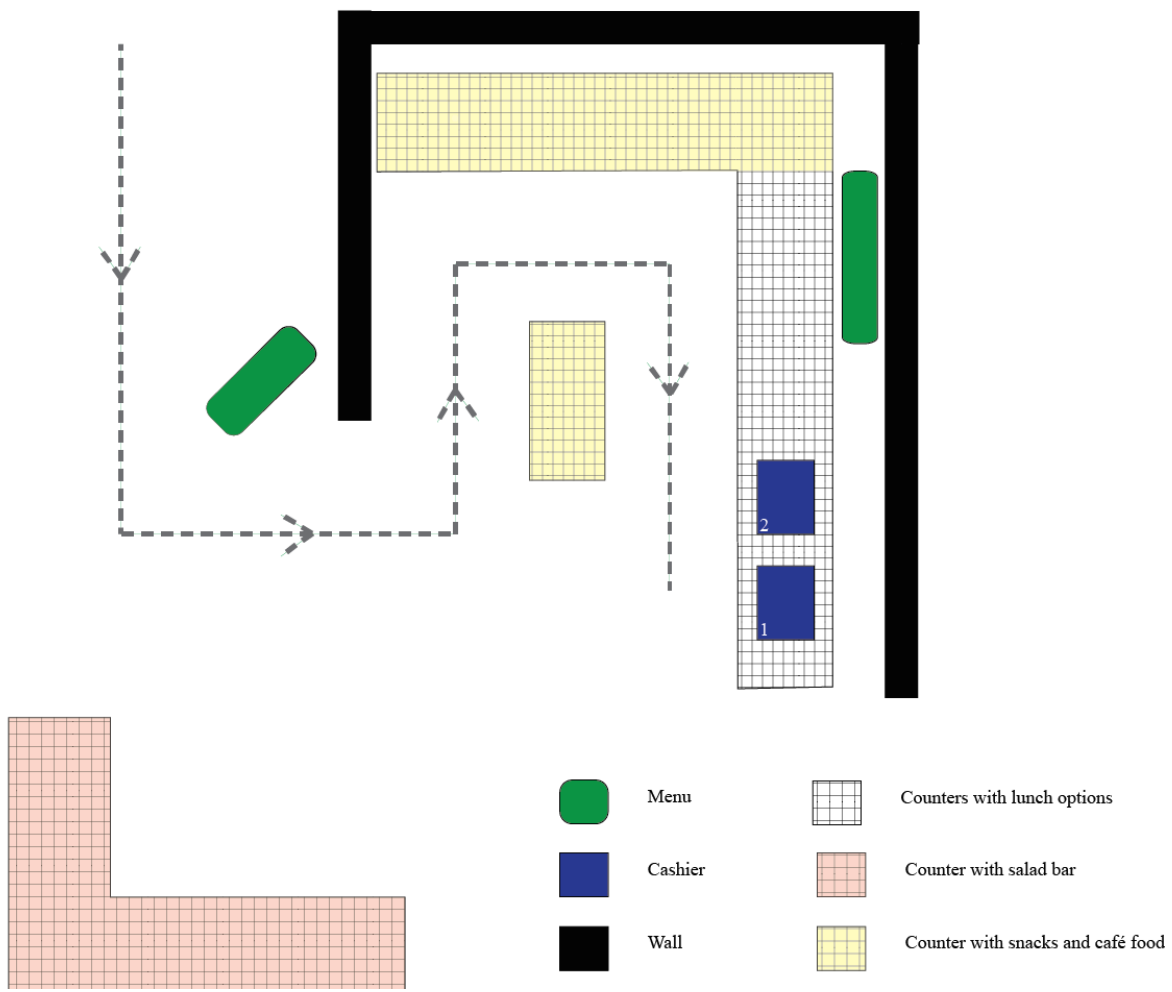

Figure A1. Outline of the cafeteria Kaffebaren Ångströms.

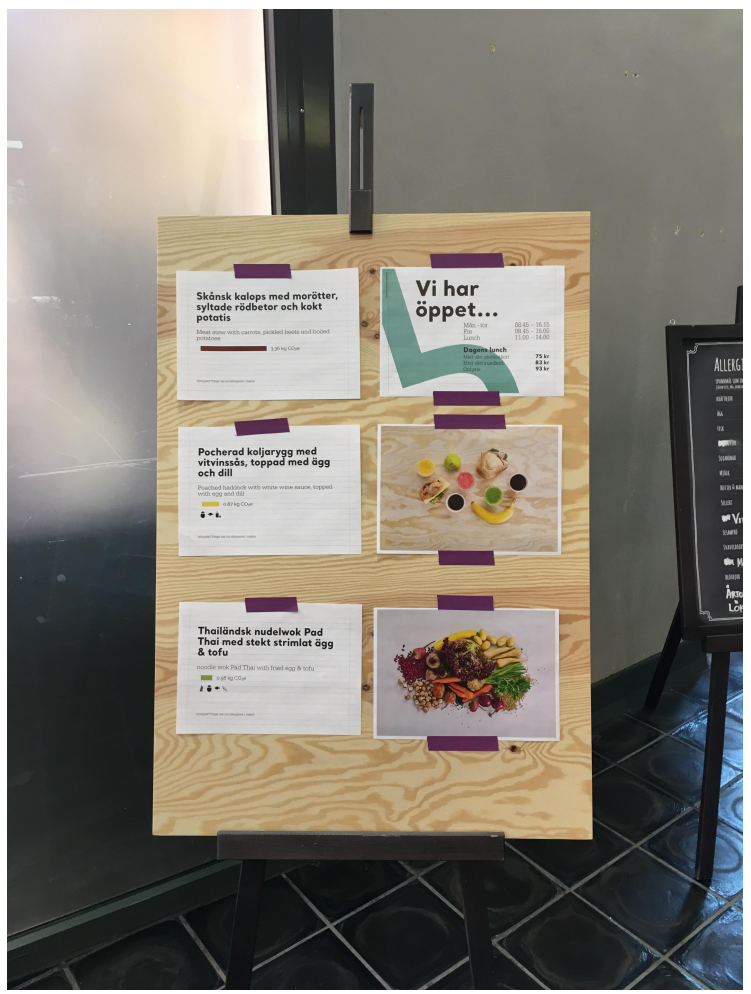

Figure A2. Example of menu board, control day. 


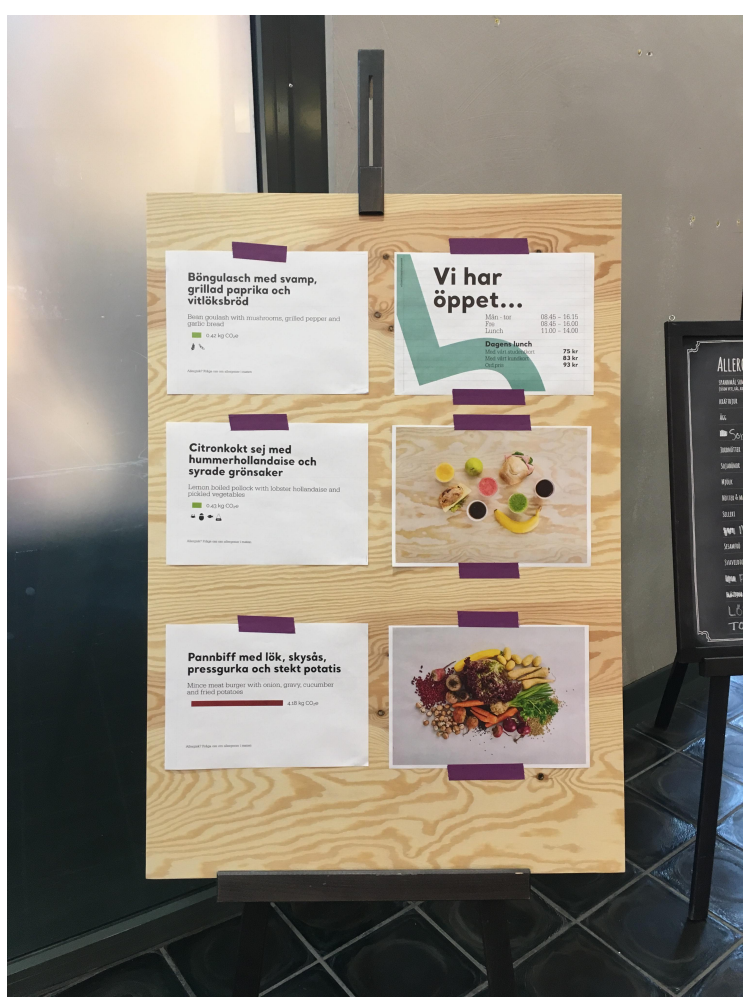

Figure A3. Example of menu board, treatment day.

\section{Appendix B. Robustness}

The regressions outlined below tests the sensitivity of the results. The regressions controlling for the type of dish (for the meat and the vegetarian option) are shown. Furthermore, the beta regression model is used and lastly the way of how to handle the misreported values is altered.

\section{Appendix B.1. Controlling for Type of Dish}

Conditioning the treatment effect on the type of meal offered will account for the popularity of the option. However, due to the limited sample size in relation to the large number of conditional variables when the categories are accounted for in the regressions, the estimates of those specifications will need to be carefully discussed before any conclusion is drawn.

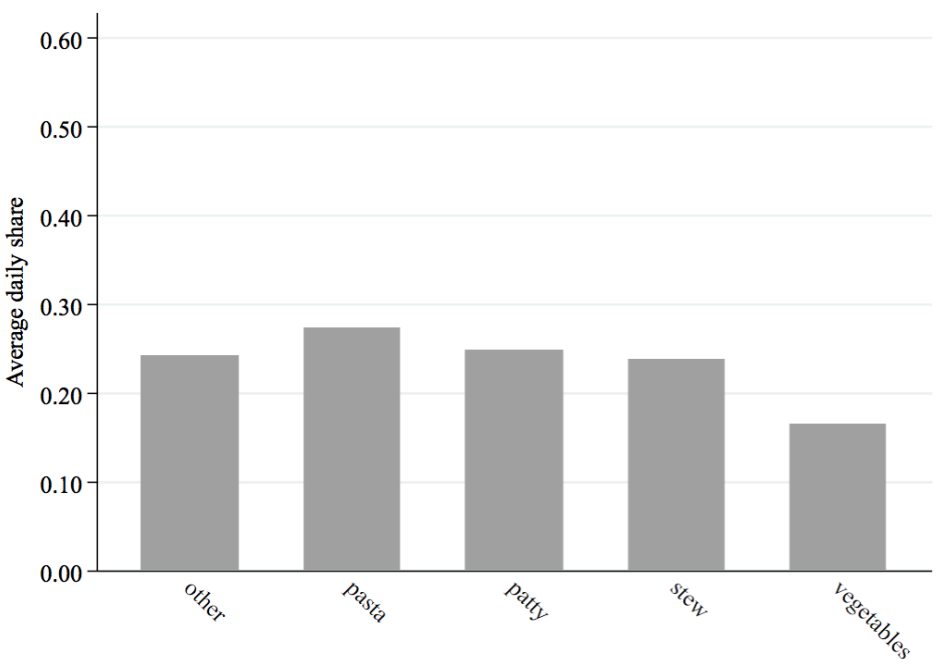

Figure A4. Share of vegetarian option sold by category. 
Figure A5 reveals that the most popular categories for the vegetarian option is pasta and patty. For the meat option the most popular category is fried, closely followed by patty. In Table A1 the regression results when conditioning the estimates on the type of vegetarian and type of meat options are shown. Column (1) in Table A1 is the same as column (4) in Tables 3 and 4.

The estimated effect on the share of meat option sold when controlling for the type of meat and vegetarian is robust and similar to previous results. The estimated effect on the share of vegetarian options sold is not drastically changed. The specifications in column (2) and (3) in Table A1 have a large number of conditional variables in relation to the total sample size. Thus, they shall not be trusted and no further conclusions by conditioning the regression results on the type of meal cannot be drawn.

Table A1. Controlling for type of dish.

(1) (2) (3)

\begin{tabular}{|c|c|c|c|}
\hline Variables & & & \\
\hline \multicolumn{4}{|c|}{ Panel A: Share of meat option sold } \\
\hline Treatment & $\begin{array}{c}-0.0605^{* *} \\
{[0.0259]}\end{array}$ & $\begin{array}{c}-0.0561 * \\
{[0.0285]}\end{array}$ & $\begin{array}{c}-0.0588^{* *} \\
{[0.0275]}\end{array}$ \\
\hline Dummy for 2 meat & $\begin{array}{c}0.134 \\
{[0.0973]}\end{array}$ & $\begin{array}{c}0.134 \\
{[0.111]}\end{array}$ & $\begin{array}{c}0.143 \\
{[0.0866]}\end{array}$ \\
\hline Dummy for 2 veg & $\begin{array}{l}-0.0328 \\
{[0.0942]}\end{array}$ & $\begin{array}{c}-0.0352 \\
{[0.106]}\end{array}$ & $\begin{array}{l}-0.0675 \\
{[0.0694]}\end{array}$ \\
\hline Total & $\begin{array}{c}0.000321 \\
{[0.000597]}\end{array}$ & $\begin{array}{c}0.000405 \\
{[0.000700]}\end{array}$ & $\begin{array}{c}0.000250 \\
{[0.000522]}\end{array}$ \\
\hline Constant & $\begin{array}{c}0.510 * * * \\
{[0.103]}\end{array}$ & $\begin{array}{c}0.495^{* * *} \\
{[0.140]}\end{array}$ & $\begin{array}{c}0.421^{* * *} \\
{[0.126]}\end{array}$ \\
\hline Observations & 50 & 50 & 50 \\
\hline Adjusted R-squared & 0.232 & 0.162 & 0.311 \\
\hline Weekday fixed effects & YES & YES & YES \\
\hline Vegetarian type & $\mathrm{NO}$ & YES & YES \\
\hline Meat type & $\mathrm{NO}$ & $\mathrm{NO}$ & YES \\
\hline \multicolumn{4}{|c|}{ Panel B: Share of vegetarian option sold } \\
\hline Treatment & $\begin{array}{l}0.0386 * \\
{[0.0223]}\end{array}$ & $\begin{array}{c}0.0280 \\
{[0.0211]}\end{array}$ & $\begin{array}{c}0.0248 \\
{[0.0231]}\end{array}$ \\
\hline Dummy for 2 veg & $\begin{array}{l}0.128^{* * *} \\
{[0.0315]}\end{array}$ & $\begin{array}{l}0.139 * * * \\
{[0.0402]}\end{array}$ & $\begin{array}{l}0.137 * * \\
{[0.0521]}\end{array}$ \\
\hline Dummy for 2 meat & $\begin{array}{l}-0.0451 \\
{[0.0413]}\end{array}$ & $\begin{array}{l}-0.0306 \\
{[0.0565]}\end{array}$ & $\begin{array}{l}-0.0319 \\
{[0.0622]}\end{array}$ \\
\hline Total & $\begin{array}{c}1.44 \times 10^{-5} \\
{[0.000405]}\end{array}$ & $\begin{array}{l}-0.000221 \\
{[0.000445]}\end{array}$ & $\begin{array}{r}-0.000249 \\
{[0.000475]}\end{array}$ \\
\hline Constant & $\begin{array}{l}0.183 * * * \\
{[0.0620]}\end{array}$ & $\begin{array}{l}0.210^{*} \\
{[0.104]}\end{array}$ & $\begin{array}{c}0.204 \\
{[0.125]}\end{array}$ \\
\hline Observations & 50 & 50 & 50 \\
\hline Adjusted R-squared & 0.232 & 0.162 & 0.311 \\
\hline Weekday fixed effects & YES & YES & YES \\
\hline Vegetarian type & $\mathrm{NO}$ & YES & YES \\
\hline Meat type & $\mathrm{NO}$ & NO & YES \\
\hline
\end{tabular}

Robust standard errors in brackets, ${ }^{* * *} p<0.01,{ }^{* *} p<0.05,{ }^{*} p<0.1$. 


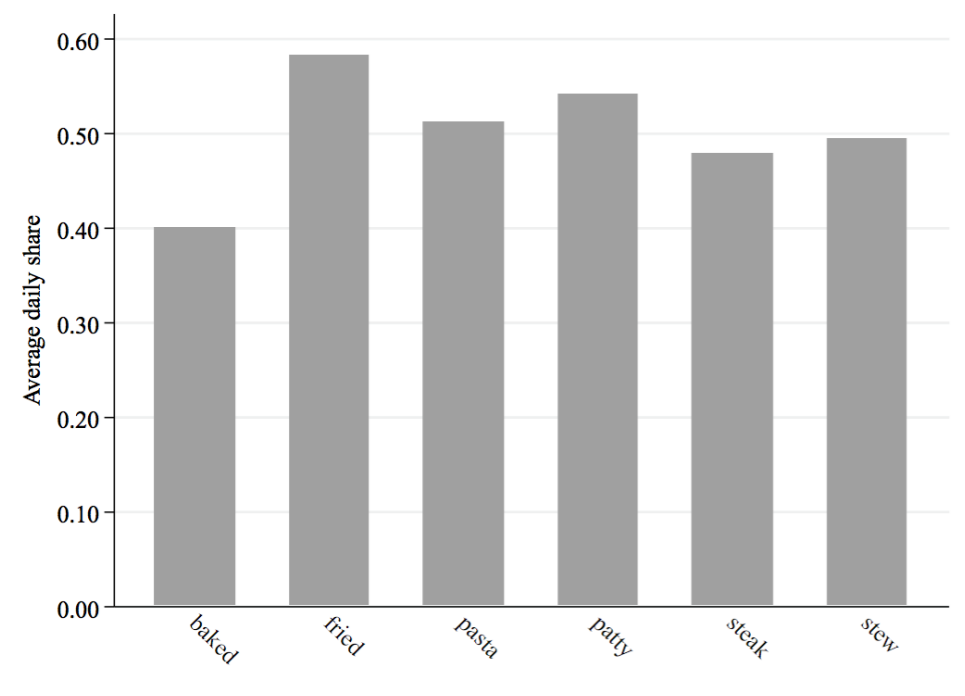

Figure A5. Share of meat option sold by category.

\section{Appendix B.2. Beta Regressions}

A beta regression model is used to test the robustness of the OLS estimates. It is suitable since it only predicts values between 0 and 1 , non-inclusive. However, the estimates obtained have to be converted to marginal treatment effects at the mean for interpretation to be possible.

As seen in Table A2, using a beta regression, the estimated treatment effect does not differ substantially from the OLS estimates in Tables $3-5$. This holds for all the different models, altering the dependent variable, as well as for the specifications for each model. The reported coefficients are estimates of the marginal treatment effect at the conditional mean. These are calculated using the change in log odds, which is what is originally reported due to the logarithmic link in the beta regression model.

\section{Appendix B.3. Altering How to Handle the Misreported Values}

As described in Section 5, for some days the cash registers reported that some fish options were purchased even though no fish was served. This is due to misreporting when the purchase is registered in the cashiers, a human error. Since the menus are available, the days when this happened were tracked and I argue that dividing them 50/50 between the meat and vegetarian counts is the most valid way to go. To test this however, two alternative ways to handle them are tested as well. These include moving the misreported values to the vegetarian count if two vegetarian options were offered and to the meat count if two meat options and removing them completely (adjusting the total count accordingly). Tables A3 and A4 show the results when using the different approaches (specified in the titles). The one significant treatment effect on the share of vegetarian option sold becomes statistically insignificant (column (5)). Other than that, no major change in the estimates is seen in terms of effect size and they do not seem to be sensitive to how the misreported values for fish are handled. Thus, the results found from the main analysis are considered to be robust to this aspect of the data. 
Table A2. Beta regressions.

\begin{tabular}{|c|c|c|c|c|c|}
\hline & (1) & (2) & (3) & (4) & (5) \\
\hline \multicolumn{6}{|l|}{ Variables } \\
\hline \multicolumn{6}{|c|}{ Panel A: Share of meat option sold } \\
\hline Treatment & $\begin{array}{c}-0.0711^{* * *} \\
{[0.0275]}\end{array}$ & $\begin{array}{c}-0.0728 * * * \\
{[0.0279]}\end{array}$ & $\begin{array}{c}-0.0543 * * \\
{[0.0240]}\end{array}$ & $\begin{array}{c}-0.0531 \text { ** } \\
{[0.0250]}\end{array}$ & $\begin{array}{c}-0.0589 * * \\
{[0.0234]}\end{array}$ \\
\hline Dummy for 2 veg & & $\begin{array}{l}-0.0133 \\
{[0.0262]}\end{array}$ & $\begin{array}{c}0.0107 \\
{[0.0246]}\end{array}$ & $\begin{array}{c}0.0102 \\
{[0.0247]}\end{array}$ & $\begin{array}{l}-0.0345 \\
{[0.0852]}\end{array}$ \\
\hline Dummy for 2 meat & & & $\begin{array}{l}0.186^{* * *} \\
{[0.0263]}\end{array}$ & $\begin{array}{l}0.184^{* * *} \\
{[0.0257]}\end{array}$ & $\begin{array}{c}0.137 \\
{[0.0891]}\end{array}$ \\
\hline Total & & & & $\begin{array}{c}0.000247 \\
{[0.000586]}\end{array}$ & $\begin{array}{c}0.000336 \\
[0.000539]]\end{array}$ \\
\hline Observations & 50 & 50 & 50 & 50 & 50 \\
\hline \multicolumn{6}{|c|}{ Panel B: Share of vegetarian option sold } \\
\hline Treatment & $\begin{array}{c}-0.00772 \\
{[0.0355]} \\
\end{array}$ & $\begin{array}{c}0.0211 \\
{[0.0222]}\end{array}$ & $\begin{array}{c}0.0295 \\
{[0.0221]} \\
\end{array}$ & $\begin{array}{c}0.0268 \\
{[0.0220]} \\
\end{array}$ & $\begin{array}{l}0.0344 * \\
{[0.0198]}\end{array}$ \\
\hline Dummy for 2 veg & & $\begin{array}{l}0.217^{* * *} \\
{[0.0188]}\end{array}$ & $\begin{array}{l}0.228^{* * *} \\
{[0.0198]}\end{array}$ & $\begin{array}{l}0.229 * * * \\
{[0.0195]}\end{array}$ & $\begin{array}{l}0.103^{* * *} \\
{[0.0256]}\end{array}$ \\
\hline Dummy for 2 meat & & & $\begin{array}{c}0.0832 * * * \\
{[0.0263]}\end{array}$ & $\begin{array}{c}0.0859 * * * \\
{[0.0246]}\end{array}$ & $\begin{array}{l}-0.0418 \\
{[0.0338]}\end{array}$ \\
\hline Total & & & & $\begin{array}{l}-0.000362 \\
{[0.000424]}\end{array}$ & $\begin{array}{c}2.81 \times 10^{-5} \\
{[0.000343]}\end{array}$ \\
\hline Observations & 50 & 50 & 50 & 50 & 50 \\
\hline \multicolumn{6}{|c|}{ Panel C: Share of fish option sold } \\
\hline Treatment & $\begin{array}{c}0.00951 \\
{[0.0280]}\end{array}$ & & & $\begin{array}{l}0.00136 \\
{[0.0261]}\end{array}$ & $\begin{array}{c}0.00552 \\
{[0.0268]}\end{array}$ \\
\hline Total & & & & $\begin{array}{c}-0.001311^{* *} \\
{[0.000579]}\end{array}$ & $\begin{array}{c}-0.00130^{* *} \\
{[0.000607]}\end{array}$ \\
\hline Observations & 30 & & & 30 & 30 \\
\hline Weekday fixed effects & $\mathrm{NO}$ & $\mathrm{NO}$ & $\mathrm{NO}$ & $\mathrm{NO}$ & YES \\
\hline
\end{tabular}

Table A3. Share of vegetarian option sold, alternative ways of handling misreported values.
(1)
(2)
(3)
(4)
(5)

\begin{tabular}{lccccc}
\hline Variables & \multicolumn{5}{c}{} \\
\hline \multicolumn{1}{c}{ Panel A: Misreported values assigned to the category } & which had two options \\
\hline Treatment & -0.00613 & 0.0248 & 0.0301 & 0.0276 & 0.0352 \\
& {$[0.0405]$} & {$[0.0223]$} & {$[0.0227]$} & {$[0.0225]$} & {$[0.0216]$} \\
\hline Dummy for 2 veg & & $0.258^{* * *}$ & $0.265^{* * *}$ & $0.266^{* * *}$ & $0.145^{* * *}$ \\
& {$[0.0239]$} & {$[0.0250]$} & {$[0.0246]$} & {$[0.0307]$} \\
\hline Dummy for 2 meat & & & $0.0548^{* * *}$ & $0.0584^{* * *}$ & $-0.0666^{*}$ \\
& & & {$[0.0203]$} & {$[0.0187]$} & {$[0.0365]$} \\
\hline Total & & & & -0.000456 & $-5.09 \times 10^{-5}$ \\
& & & & {$[0.000402]$} & {$[0.000401]$} \\
\hline Constant & $0.313^{* * *}$ & $0.220^{* * *}$ & $0.211^{* * *}$ & $0.284^{* * *}$ & $0.196^{* * *}$ \\
& {$[0.0267]$} & {$[0.0160]$} & {$[0.0186]$} & {$[0.0695]$} & {$[0.0628]$} \\
\hline Adjusted R-squared & -0.020 & 0.687 & 0.691 & 0.693 & 0.696 \\
\hline
\end{tabular}


Table A3. Cont.

(1)

(2)

(3)

(4)

(5)

\begin{tabular}{|c|c|c|c|c|c|}
\hline \multicolumn{6}{|l|}{ Variables } \\
\hline \multicolumn{6}{|c|}{ Panel B: Misreported values removed and total adjusted } \\
\hline Treatment & $\begin{array}{c}-0.00336 \\
{[0.0387]}\end{array}$ & $\begin{array}{c}0.0252 \\
{[0.0235]}\end{array}$ & $\begin{array}{c}0.0320 \\
{[0.0239]}\end{array}$ & $\begin{array}{c}0.0298 \\
{[0.0238]}\end{array}$ & $\begin{array}{c}0.0381 \\
{[0.0227]}\end{array}$ \\
\hline Dummy for 2 veg & & $\begin{array}{l}0.238^{* * *} \\
{[0.0253]}\end{array}$ & $\begin{array}{l}0.247^{* * *} \\
{[0.0264]}\end{array}$ & $\begin{array}{l}0.246^{* * *} \\
{[0.0265]}\end{array}$ & $\begin{array}{l}0.125^{* * *} \\
{[0.0299]}\end{array}$ \\
\hline Dummy for 2 meat & & & $\begin{array}{c}0.0705^{* *} \\
{[0.0270]}\end{array}$ & $\begin{array}{c}0.0709 * * * \\
{[0.0243]}\end{array}$ & $\begin{array}{l}-0.0507 \\
{[0.0394]}\end{array}$ \\
\hline Total & & & & $\begin{array}{l}-0.000375 \\
{[0.000407]}\end{array}$ & $\begin{array}{c}2.57 \times 10^{-5} \\
{[0.000374]}\end{array}$ \\
\hline Constant & $\begin{array}{l}0.307^{* * *} \\
{[0.0247]}\end{array}$ & $\begin{array}{l}0.222 \text { *** } \\
{[0.0164]}\end{array}$ & $\begin{array}{l}0.210^{* * *} \\
{[0.0191]}\end{array}$ & $\begin{array}{l}0.270 * * * \\
{[0.0703]}\end{array}$ & $\begin{array}{l}0.181^{* * *} \\
{[0.0569]}\end{array}$ \\
\hline Adjusted R-squared & -0.021 & 0.638 & 0.650 & 0.649 & 0.654 \\
\hline $\begin{array}{l}\text { Observations } \\
\text { Weekday fixed effects }\end{array}$ & $\begin{array}{c}50 \\
\mathrm{NO}\end{array}$ & $\begin{array}{c}50 \\
\mathrm{NO}\end{array}$ & $\begin{array}{c}50 \\
\mathrm{NO}\end{array}$ & $\begin{array}{c}50 \\
\mathrm{NO}\end{array}$ & $\begin{array}{c}50 \\
\text { YES }\end{array}$ \\
\hline
\end{tabular}

Table A4. Share of meat option sold, alternative ways of handling misreported values.

\begin{tabular}{|c|c|c|c|c|c|}
\hline & (1) & (2) & (3) & (4) & (5) \\
\hline \multicolumn{6}{|l|}{ Variables } \\
\hline \multicolumn{6}{|c|}{ Panel A: Misreported values assigned to the category which had two options } \\
\hline Treatment & $\begin{array}{c}-0.0679 * * \\
{[0.0292]}\end{array}$ & $\begin{array}{c}-0.0516 \text { ** } \\
{[0.0249]}\end{array}$ & $\begin{array}{c}-0.0525^{* *} \\
{[0.0243]}\end{array}$ & $\begin{array}{c}-0.0510 * \\
{[0.0259]}\end{array}$ & $\begin{array}{c}-0.0563 \text { ** } \\
{[0.0255]}\end{array}$ \\
\hline Dummy for 2 veg & & & $\begin{array}{c}-0.00656 \\
{[0.0254]}\end{array}$ & $\begin{array}{c}-0.00713 \\
{[0.0256]}\end{array}$ & $\begin{array}{l}-0.0524 \\
{[0.0978]}\end{array}$ \\
\hline Dummy for 2 meat & & $\begin{array}{l}0.205^{* * *} \\
{[0.0141]}\end{array}$ & $\begin{array}{l}0.202 * * * \\
{[0.0173]}\end{array}$ & $\begin{array}{l}0.200^{* * *} \\
{[0.0173]}\end{array}$ & $\begin{array}{c}0.154 \\
{[0.100]}\end{array}$ \\
\hline Total & & & & $\begin{array}{c}0.000284 \\
{[0.000628]}\end{array}$ & $\begin{array}{c}0.000378 \\
{[0.000599]}\end{array}$ \\
\hline Constant & $\begin{array}{l}0.560 \text { *** } \\
{[0.0189]}\end{array}$ & $\begin{array}{l}0.535^{* * *} \\
{[0.0139]}\end{array}$ & $\begin{array}{l}0.538^{* * *} \\
{[0.0166]}\end{array}$ & $\begin{array}{c}0.492^{* * *} \\
{[0.108]}\end{array}$ & $\begin{array}{c}0.497^{* * *} \\
{[0.104]}\end{array}$ \\
\hline Adjusted R-squared & 0.083 & 0.339 & 0.325 & 0.316 & 0.276 \\
\hline \multicolumn{6}{|c|}{ Panel B: Misreported values removed and total adjusted } \\
\hline Treatment & $\begin{array}{c}-0.0719^{* *} \\
{[0.0286]}\end{array}$ & $\begin{array}{c}-0.0574 * * \\
{[0.0252]}\end{array}$ & $\begin{array}{c}-0.0554^{* *} \\
{[0.0253]}\end{array}$ & $\begin{array}{c}-0.0542 * * \\
{[0.0267]}\end{array}$ & $\begin{array}{c}-0.0601 \text { ** } \\
{[0.0262]}\end{array}$ \\
\hline Dummy for 2 meat & & & & $\begin{array}{l}0.186^{* * *} \\
{[0.0218]}\end{array}$ & $\begin{array}{c}0.143 \\
{[0.0942]}\end{array}$ \\
\hline Dummy for 2 veg & & & $\begin{array}{c}0.0130 \\
{[0.0268]}\end{array}$ & $\begin{array}{c}0.0138 \\
{[0.0272]}\end{array}$ & $\begin{array}{l}-0.0276 \\
{[0.0919]}\end{array}$ \\
\hline Total & & & & $\begin{array}{c}0.000215 \\
{[0.000581]}\end{array}$ & $\begin{array}{c}0.000282 \\
{[0.000556]}\end{array}$ \\
\hline Constant & $\begin{array}{l}0.566^{* * *} \\
{[0.0176]}\end{array}$ & $\begin{array}{l}0.545^{* * *} \\
{[0.0130]}\end{array}$ & $\begin{array}{c}0.539 * * * \\
{[0.0171]}\end{array}$ & $\begin{array}{l}0.505^{* * *} \\
{[0.0993]}\end{array}$ & $\begin{array}{l}0.516^{* * *} \\
{[0.0962]}\end{array}$ \\
\hline Adjusted R-squared & 0.098 & 0.302 & 0.290 & 0.278 & 0.234 \\
\hline $\begin{array}{l}\text { Observations } \\
\text { Weekday fixed effects }\end{array}$ & $\begin{array}{l}50 \\
\text { NO }\end{array}$ & $\begin{array}{l}50 \\
\mathrm{NO}\end{array}$ & $\begin{array}{c}50 \\
\text { NO }\end{array}$ & $\begin{array}{l}50 \\
\mathrm{NO}\end{array}$ & $\begin{array}{l}50 \\
\text { YES }\end{array}$ \\
\hline
\end{tabular}




\section{References}

1. Thaler, R.; Sustain, C. Nudge: Improving Decisions about Health, Wealth and Happiness; Yale University Press: London, UK, 2008.

2. Scarborough, P.; Appleby, P.N.; Mizdrak, A.; Briggs, A.D.; Travis, R.C.; Bradbury, K.E.; Key, T.J. Dietary greenhouse gas emissions of meat-eaters, fish-eaters, vegetarians and vegans in the UK. Clim. Chang. 2014, 125, 179-192. [CrossRef] [PubMed]

3. Carlsson-Kanyama, A.; González, A.D. Potential contributions of food consumption patterns to climate change. Am. J. Clin. Nutr. 2009, 89, 1704S-1709S. [CrossRef]

4. Stehfest, E.; Bouwman, L.; Van Vuuren, D.P.; Den Elzen, M.G.; Eickhout, B.; Kabat, P. Climate benefits of changing diet. Clim. Chang. 2009, 95, 83-102. [CrossRef]

5. Harrison, G.W.; List, J.A. Field experiments. J. Econ. Lit. 2004, 42, 1009-1055. [CrossRef]

6. UNFCCC. The Paris Agreement; United Nations: Paris, France, 2015.

7. Swedish Environmental Protection Agency. Hushållens Utsläpp ståR för Två Tredjedelar av de Totala Konsumtionsbaserade Växthusgasutsläppen. Resterande Tredjedel Kommer Från Offentlig Konsumtion Och Investeringar; Swedish Environmental Protection Agency: Stockholm, Sweden, 2018.

8. Hedenus, F.; Wirsenius, S.; Johansson, D.J. The importance of reduced meat and dairy consumption for meeting stringent climate change targets. Clim. Chang. 2014, 124, 79-91. [CrossRef]

9. Kallbekken, S.; Sælen, H. 'Nudging' hotel guests to reduce food waste as a win-win environmental measure. Econ. Lett. 2013, 119, 325-327. [CrossRef]

10. Wansink, B.; Hanks, A.S. Slim by design: Serving healthy foods first in buffet lines improves overall meal selection. PLoS ONE 2013, 8, e77055. [CrossRef]

11. Wansink, B.; Painter, J.E.; North, J. Bottomless bowls: Why visual cues of portion size may influence intake. Obes. Res. 2005, 13, 93-100. [CrossRef]

12. Wisdom, J.; Downs, J.S.; Loewenstein, G. Promoting healthy choices: Information versus convenience. Am. Econ. J. Appl. Econ. 2010, 2, 164-78. [CrossRef]

13. Willett, W.; Rockström, J.; Loken, B.; Springmann, M.; Lang, T.; Vermeulen, S.; Garnett, T.; Tilman, D.; DeClerck, F.; Wood, A.; et al. Food in the Anthropocene: The EAT-Lancet Commission on healthy diets from sustainable food systems. Lancet 2019, 393, 447-492. [CrossRef]

14. Nisa, C.F.; Bélanger, J.J.; Schumpe, B.M.; Faller, D.G. Meta-analysis of randomised controlled trials testing behavioural interventions to promote household action on climate change. Nat. Commun. 2019, 10, 4545. [CrossRef] [PubMed]

15. Garnett, E.E.; Balmford, A.; Sandbrook, C.; Pilling, M.A.; Marteau, T.M. Impact of increasing vegetarian availability on meal selection and sales in cafeterias. Proc. Natl. Acad. Sci. USA 2019, 116, 20923-20929. [CrossRef] [PubMed]

16. Rubinstein, A.; Salant, Y. A model of choice from lists. Theor. Econ. 2006, 1, 3-17.

17. Glanzer, M.; Cunitz, A.R. Two storage mechanisms in free recall. J. Verb. Learn. Verb. Behav. 1966, 5, 351-360. [CrossRef]

18. Krosnick, J.A. Response strategies for coping with the cognitive demands of attitude measures in surveys. Appl. Cognit. Psychol. 1991, 5, 213-236. [CrossRef]

19. Miller, J.M.; Krosnick, J.A. The impact of candidate name order on election outcomes. Public Opin. Q. 1998, 62, 291-330. [CrossRef]

20. Koppell, J.G.; Steen, J.A. The effects of ballot position on election outcomes. J. Politics 2004, 66, 267-281. [CrossRef]

21. Feenberg, D.; Ganguli, I.; Gaule, P.; Gruber, J. It's good to be first: Order bias in reading and citing NBER working papers. Rev. Econ. Stat. 2017, 99, 32-39. [CrossRef]

22. Xu, Y.C.; Kim, H.W. Order effect and vendor inspection in online comparison shopping. J. Retail. 2008, 84, 477-486. [CrossRef]

23. Ghose, A.; Yang, S. An empirical analysis of search engine advertising: Sponsored search in electronic markets. Manag. Sci. 2009, 55, 1605-1622. [CrossRef]

24. Andersson, O.; Andersson, T. Timing and presentation effects in sequential auctions. J. Mech. Inst. Des. 2017, 2, 39-55. [CrossRef]

25. Wansink, B.; Love, K. Slim by design: Menu strategies for promoting high-margin, healthy foods. Int. J. Hosp. Manag. 2014, 42, 137-143. [CrossRef]

26. Borgmeier, I.; Westenhoefer, J. Impact of different food label formats on healthiness evaluation and food choice of consumers: A randomized-controlled study. BMC Public Health 2009, 9, 184. [CrossRef] [PubMed]

27. van Glider Cooke, S. Why Going Green Can Mean Big Money for Fast-Food Chains. Time, 9 April 2012, p. 1.

28. Andersson, O.; Ingebretsen Carlson, J.; Wengström, E. Differences Attract: An Experimental Study of Focusing in Economic Choice; IFN Working Paper No. 1145; IFN: Stockholm, Sweden, 2016.

29. Wansink, B.; Sobal, J. Mindless eating: The 200 daily food decisions we overlook. Environ. Behav. 2007, 39, 106-123. [CrossRef]

30. Popkin, B.M. Recent dynamics suggest selected countries catching up to US obesity. Am. J. Clin. Nutr. 2009, 91, 284S-288S. [CrossRef] [PubMed]

31. Van Kleef, E.; Seijdell, K.; Vingerhoeds, M.H.; de Wijk, R.A.; van Trijp, H.C. The effect of a default-based nudge on the choice of whole wheat bread. Appetite 2018, 121, 179-185. [CrossRef]

32. Gravert, C.; Kurz, V. Nudging à la carte: A field experiment on climate-friendly food choice. Behav. Public Policy 2019, 1-18. [CrossRef]

33. Hainmueller, J.; Hiscox, M.J.; Sequeira, S. Consumer demand for fair trade: Evidence from a multistore field experiment. Rev. Econ. Stat. 2015, 97, 242-256. [CrossRef] 
34. Campbell-Arvai, V.; Arvai, J.; Kalof, L. Motivating sustainable food choices: The role of nudges, value orientation, and information provision. Environ. Behav. 2014, 46, 453-475. [CrossRef]

35. Kurz, V. Nudging to reduce meat consumption: Immediate and persistent effects of an intervention at a university restaurant. J. Environ. Econ. Manag. 2018, 90, 317-341. [CrossRef]

36. OSF. Menu Nudge in University Cafeteria; OSF: Ashland, OR, USA, 2019. [CrossRef]

37. Bordalo, P.; Gennaioli, N.; Shleifer, A. Salience and consumer choice. J. Polit. Econ. 2013, 121, 803-843. [CrossRef] 